\title{
Legal Politics and Strategy on Protection of Women from Violence in Human Rights Context
}

\author{
Margie Gladies Sopacua \\ Faculty of Law, Pattimura University \\ J1. Ir. M. Putuhena, Poka, Teluk Ambon, Ambon, Maluku, 97233, Indonesia
}

\begin{abstract}
In the past, violence against women was viewed as common actions and was tolerated, especially if it occurred within a household. People were often powerless to protect the victims, and any kinds of intervention were considered as taboo, due to the essence of domestic relationship that was portrayed as private matters. Not only domestic violence, but other acts of violence such as sexual harassment, most of the time, women became victims of these violence. However, as the community progressed, many of these actions were later criminalized because it led to rape and murder. In addition, today's discourse on violence against women is something that is widely discussed by practitioners, non-governmental organizations (NGOs), academics and the wider community. This was motivated by the demands of an increasingly complex role of women, along with the growing progressive view on human rights which see both sexes as equal. Violence against women is an act of human rights violations experienced by women. Therefore, the United Nations (UN) organization later recognize violence against women as a crime. The existence of the Convention on the Elimination of All Forms Discrimination Against Women (CEDAW), 2. Declaration on the Elimination of Violence Against Woman, Beijing Declaration and Platform for Action, and other related international conventions require legal politics to seek harmonization and synchronization of national regulations which ultimately resulted in Law of the Republic of Indonesia Number 23 Year 2004 concerning the Elimination of Domestic Violence as an effort to minimize the crime against women. But it is not enough to eliminate the violence due to various factors, especially the law enforcement officers. Therefore, another strategy is strongly needed to support the protection of women from violence in the context of human rights.
\end{abstract}

Keywords: human rights, legal politics, strategy, woman protection.

DOI: $10.7176 /$ RHSS/9-4-04

\section{Introduction}

Today's discourse on violence against women is something that is widely discussed by practitioners, NGOs, academics and the wider community. This was motivated by the demands of an increasingly complex role of women, along with the growing progressive view on human rights which see both sexes as equal. Violence against women is an act of human rights violations experienced by women. Therefore, the UN later recognize violence against women as a crime.

Violence against women is no longer seen as individual problem, but has caught the attention as national problem and even a global problem. In certain cases, violence against women can be said to be a transnational problem. It is categorized as global problems due to the existing international laws concerning the phenomenon as confirmed by Muladi in the following instruments:

1. Viena Declaration: Convention on the Elimination of All Forms Discrimination Against Women / CEDAW (1979).

2. Declaration on the Elimination of Violence Against Woman (1993).

3. Bejing Declaration and Platform for Action (1994). ${ }^{1}$

Violence against women as global matter, has worried every citizen in the world, not limited to developing countries but also developed countries that are said to be very respectful and mindful toward human rights, like the United States. ${ }^{2}$ Indonesia, as a developing country, has a poor reputation towards the issue of human rights violations, one of which is the violation of women's rights. Furthermore, violations of women's rights can be classified as acts of violence against women.

The National Commission on Violence Against Women (Komnas Perempuan) noted that in 2014 there were 4,475 cases of sexual violence against women and girls. In 2015, there was an increase to 6,499 cases, In 2016 , the number of cases were slightly decreased to 5,785 cases and in 2017 there were 2,979 cases of sexual violence in the realm of domestic violence or personal relations and 2,670 cases in the public or community

\footnotetext{
${ }^{1}$ Muladi, (1997), Hak Asasi Manusia, Politik dan Sistem Peradilan Pidana, Universitas Diponegoro, Semarang, p. 31.

${ }^{2}$ Reni Widyastuti, (2009), Peran Hukum Dalam Memberikan Perlindungan Terhadap Perempuan Dari Tindak Kekerasan di Era Globalisasi, Mimbar Hukum, 21(2), p. 396. see https://media.neliti.com/media/publications/40556-ID-peran-hukum-dalam-memberikanperlindungan-terhadap-perempuan-dari-tindak-kekerasan.pdf
} 
domain. $^{1}$

The law views all citizen as equal with no exceptions. ${ }^{2}$ Therefore, law is a set of rules that must be adhered to and obeyed by every member of the community. If the law is violated or ignored, then the offender must be punished. ${ }^{3}$ Law as a social phenomenon cannot be separated from the society itself and there should not be a society that does not know the law, as expressed in a Roman phrase by Marcus Tullius Cicero, which states that "ubi societas ibi ius" which literal translations means; where there is a family there is a law. ${ }^{4}$ In relation to this explanation, according to Roscoe Pound, the law must be viewed or seen as a social institution that functions to fulfill social needs and the obligation of legal science is for the development of a framework by which social needs can be fully fulfilled. ${ }^{5}$

Concerns about victims of violence are increasingly being expressed due to the large number of cases that left unresolved while the impact to the victims is permanent and brings prolonged trauma. Violence can happen to anyone and anywhere. If carefully explored, the number of violence towards women tends to increase and have a very serious impact such as sexual violence, rape, sexual abuse, women trafficking and domestic violence. These acts of violence are recognized as gender-based violence. ${ }^{6}$

This concept actually refers to the subordinate position of women due to the reflection of powerless and powerful. In other words, there is a power imbalance between women and men. The existence of women, who are often classified as second-class citizens, has worsened lately with the existence of various chaos that create a considerable number of new female victims, in physical violence (such as rape, obscene acts), psychological violence (eg harassment, terror) and economic violence (for example in work termination). ${ }^{7}$

In this regard, Harkristuti Harkrisnowo revealed a concerning phenomenon, that acts of violence against women that have been acknowledged as global issues, have not received attention for quite a long time in Indonesia. The public's indifference to this problem is due to social structure, people's perceptions of women and acts of violence against women, and the value of the people who always want to look harmonious and therefore difficult to recognize the existence of problems in the household whatever the risks. These are the three basic things that underline the slow progress. ${ }^{8}$

Many women's institutions have voiced out about anti-violence, but the results have not been so optimal. To this day, violence is still widely experienced by women, especially domestic violence. This can be seen from the tradition that still glorifies men and considers women to be weak creatures. And the view that force women to obey men, is a powerful weapon in perpetrating violence against women. ${ }^{9}$

Issues that arise in the community provide different perceptions in general, where women themselves get less attention and women are classified as weak. Thus, the violence experienced by women is continuously neglected and remain hidden. This view is influential and affecting how society conducts daily activities, in connection with the values that develop in the community regarding the position of women in society.

Women, often times, endures the violence they experienced in silence for various reasons. One of which is because they do not want to be known by many people and feel ashamed of it. Regardless of whether or not there is a good concern from women toward violence that they experience, it is still something that can be seen as unfair treatment. Correspondingly, every woman who becomes a victim will think that she has a share of this criminal act, even though this is not the case.

The Republic of Indonesia, which has consciously ratified many international treaties, one of which is the CEDAW with Law of the Republic of Indonesia Number 7 Year 1984 concerning Ratification of CEDAW. This is done by the government as a form of state responsibility in accordance with the mandate of the 1945 Constitution of the Republic of Indonesia which states firmly that all citizens are equal before the law and government, therefore all forms of discrimination against women must be abolished because they are not in accordance with Pancasila and the 1945 Constitution of the Republic of Indonesia. Based on the exposure, the problem that will be discussed in this paper is what are the strategy on women's protection from Law of Domestic Violence?

\section{Research Method}

According to Peter Mahmud Marzuki, research is a process to find legal rules, legal principles, and legal

\footnotetext{
${ }^{1}$ See https://www.cnnindonesia.com/menguak-data-jumlah-kekerasan-perempuan-tahun-ke-tahun

2 Arief Budiman, (2006), Teori Negara, Negara, Kekuasaan, dan Ideologi, Jakarta: PT Gramedia Pustaka Utama, p. 1

${ }^{3}$ Wahyu Affandy, (2001), Hakim dan Penegakan Hukum, Bandung: Alumni, p. 23

${ }^{4}$ Cicero in Mr. Soplanit, (1997), Kuliah Pengantar Ilmu Hukum, p. 67

${ }^{5}$ Ali Zainuddin, (2006), Filsafat Hukum, Jakarta: Sinar Grafika, p. 23

${ }^{6}$ Reni Widyastuti, Op.Cit, p. 396

${ }^{7}$ Wila Chandrawila Supriadi, (2001), Kumpulan Tulisan Perempuan dan Kekerasan dalam Perkawinan, Bandung: CV Mandar Maju, p. 32

${ }^{8}$ Harkristuti Harkrisnowo, (2001), "Tindak Kekerasan Terhadap Perempuan Dalam Perspektif Sosio Yuridis", Jurnal Hukum, Fakultas

Hukum Universitas Islam Indonesia, Yogyakarta, p. 157

${ }^{9}$ Maidin Gultom, (2012), Perlindungan Hukum Terhadap Anak dan Perempuan, Bandung: Refika Aditama, p. 22-23
} 
doctrines in order to answer the legal issues. ${ }^{1}$ This type of research is normative juridical research, which is a legal research conducted by examining library material or mere secondary legal material. ${ }^{2}$

\section{Results and Discussion}

\section{Violence Against Women in Human Rights Perspective}

Violence against women is a new concept, which was introduced during the World Conference on Women III in Nairobi, which succeeded in raising international consensus on the importance of preventing various forms of violence against women in everyday life throughout the community and providing assistance to women who were victims of violence. Because violence against women is a new concept, there is no single and clear definition from experts or observers of women's issues on the definition and its limitations. Nevertheless, it is necessary to put forward some opinions regarding this matter.

Saparinah Sadli put forward that the issue of women's rights is a universal human rights issue, by stating: “... when women from various countries who attended the 1993 World Human Rights Conference in Vienna, solidly stated that the existing human rights mechanism was not enough if it was only extended for women's needs. They demanded that gender-based violence be the agenda of the discussion every time there was a meeting that made agreements on human rights. The women's movements also demanded to monitor and strengthen efforts so that the issue of violence against women is integrated into international agreements on human rights. It is this women's solidarity that has been able to encourage the transformation of the concept of human rights according to women's needs". ${ }^{3}$

Behind the problem of women as a whole there is a great spirit related to human rights. Human rights encompass the dimensions of politics, economics, socio-culture, education, in which must be comprehensively and integrally examined. ${ }^{4}$ In 1993 , the UN General Assembly adopted a declaration opposing violence against women which was formulated in 1992 by the UN Commission on the Status of Women. ${ }^{5}$ Article 1 of the Declaration, stated that violence against women includes: every act of violence on the basis of sex differences, which results in or can cause harm or suffering to women both physically, sexually or psychologically, including threats of such acts, coercion or arbitrary deprivation of liberty, good that happens in life that is public or private. Article 2 of the Declaration states that the definition should be understood to include, but not limited to physical, sexual and psychological violence that occurs within the family and within the community, including persecution, sexual mistreatment of female children, dowry-related violence, marital rape, genital mutilation which harmful to women's health (female genital mutilation) and other traditional practices that harm women, non-marital violence, exploitative violence, sexual harassment, and intimidation in the work environment, in educational institutions, women trafficking, coercion to prostitution, and violence perpetrated by the authorities. This definition explicitly points to the roots of violence in gender relationship (gender-based roots).

In terms of the human life cycle, violence against women can be identified as follows:

a. Before birth, the types of violence include: abortion on the basis of sex selection (China, India, Korea), abuse during pregnancy, forced pregnancy such as mass rape during war.

b. During infancy, the types of violence include: killing of infants (girls), mistreatment both emotionally and psychologically, differences in treatment in the field of food and health for girls.

c. At the age of the child, the types of violence include: child marriage, circumcision, sexual treatment by family and other people, child prostitution.

d. In adolescence, the types of violence include: date rape, forced sex treatment due to economic pressure, sexual harassment in the workplace, rape, forced prostitution, women trafficking.

e. Reproductive period, the types of violence include: intimate partner violence, marital rape, murder or violence due to dowry, spousal killing, psychic mistreatment, workplace sexual abuse, rape, violence against disabled women.

f. Old age, types of violence include: violence against widows, violence against parents. ${ }^{6}$

In addition to the definition which have been explained above, the definition of violence against women is also regulated in the laws and regulations as in the Penal Code (KUHP), CEDAW, Law of the Republic of Indonesia Number 23 Year 2004 concerning the Elimination of Domestic Violence. In the Penal Code, the definition of violence is regulated in Article 89 of the Criminal Code which states that "making people

\footnotetext{
${ }^{1}$ Peter Mahmud Marzuki. (2006). Penelitian Hukum. Second Edition. Jakarta: Kencana Prenada Media Group, p. 35

${ }^{2}$ Soerjono Soekanto. (2012). Metode Penelitian Hukum. Jakarta: Raja Grafindo, p. 13

${ }^{3}$ Achie S. Luhulima, Pemahaman Bentuk-bentuk Tindak Kekerasan Terhadap Perempuan dan Alternatif Pemecahannya, Working Group

"Convention Watch" Women and Gender Research Centre, Universitas Indonesia in cooperation with New Zealand Embassy in Indonesia, PT Alumni, Bandung, 2000, p. 5

${ }^{4}$ Muladi, (2002), Demokratisasi, Hak Asasi Manusia, dan Reformasi Hukum di Indonesia, First Edition, Jakarta: The Habibie Center, p. 6162

${ }^{5}$ Francis Wahono Nitiprawira, “Anatomi Globalisasi dan Agenda Demokrasi”, Jurnal Iman, Ilmu, Budaya,1(3), September 2002, Yayasan Bhumiksara, Jakarta, p. 32

${ }^{6}$ Muladi, (1997), Hak Asasi Manusia, Politik......., Op.Cit, p. 34-35
} 
unconscious or helpless is equated with using violence".

Article 1 point 1 of Law of the Republic of Indonesia Number 23 Year 2004 states: "domestic violence is any act against a person, especially a woman, which results in physical, sexual, psychological misery or suffering and/or neglect of the household including threats to commit an act, coercion or deprivation of liberty against the law in an household scope".

Kristi Poerwandari stated that violence against women has broad scope, can take place in a personal sphere (e.g: domestic violence, rape by unknown people, gang rape). Violence against women also has physical, psychological and sexual dimensions, which often occur overlapping at the same time. ${ }^{1}$ Different women's NGOs are developing more broad definition, which includes insufficient entry in the field of socio-economic resources such as employment, as forms of violence. This is related to various forms of human rights generation (civil, political, socio-economic and cultural as well as the right to develop).

\section{Legal Politics in Developing Legal System}

Anthony Gidden ${ }^{2}$ said, with the advancement of science and technology, the world is now out of control. The development of the world today is far from the original estimate, rather than becoming more stable, orderly and predictable, as predicted by Western optimists in the Middle Ages, but it is the opposite. One of the key words that causes such conditions is the advancement of science and technology that drives globalization. In raises a variety of new risks and uncertainties that go beyond our anticipation capabilities. This tremendous change has overhauled the tradition and even religion which has been the foundation of many people. It doesn't stop there; the process transforms new values in the family and also the country. Thus, it will greatly affect everyday life with levels that have the same effect on various events at the world level both in the political, economic, social, cultural and even legal fields.

Changes in the world and its paradigm as a result of globalization show a multidimensional process that leads to a world order without boundaries between countries. Such a social system has led to endless access to information. With such a condition, there will be many negative and positive impacts on socio-cultural changes in a society at any angle, including Indonesia as part of a global community. ${ }^{3}$ As part of the international community, in addition to having the obligation to implement various international agreements that have been ratified (pacta sunt servanda principle), it has become the government's obligation to immediately harmonize and synchronize national laws with applicable international standards. Efforts to harmonize and synchronize national law with international law must be carried out while trying to accommodate international trends (international trends) in addition to paying attention to domestic aspirations. ${ }^{4}$

According to Muladi, harmonization of law emphasizes the existence of the same indicators and characteristics in legislation. While synchronization of law emphasizes that legislations may not conflict with each other (horizontal synchronization) and may not conflict with legislation in higher hierarchy (vertical synchronization). Efforts to harmonize and synchronize national law with international law must be carried out while trying to accommodate international trends in addition to paying attention to domestic aspirations. ${ }^{5}$ This means that without ignoring the dominant particularistic elements, various global trends must be seen as part of national trends. So, while still relying on a national culture that upholds the ideology of the nation while considering international trends, Indonesia must continue to strive to adapt to global developments. ${ }^{6}$ The problem of accepting or rejecting global pressure through various instruments of international law is actually a matter of the relationship between international law and national law.

International law is an orderly coordination between equal international communities. Members of the international community are subject to international law as a legal order that they receive as a set of rules and principles that bind relations between them. ${ }^{7}$ Thus, the current global pressure must indeed be addressed, coordinated and integrated into Indonesian national law. According to Muladi, the adoption of positive things that occur in the international environment cannot be carried out immediately, but must be examined according to values that originate from the ideology of the nation, namely Pancasila. ${ }^{8}$ Kartini Sekartadji ${ }^{1}$ put forward three

\footnotetext{
${ }^{1}$ Kristi Poerwandari, (2006), Kekerasan terhadap Perempuan: Tinjauan Psikologis, in Tapi Omas Ihromi et.al., Penghapusan Diskriminasi Terhadap Wanita, Bandung: Alumni, p. 277.

${ }^{2}$ Anthony Giddens, (2001), Runway World, Bagaimana Globalisasi Merombak Kehidupan Kita, Jakarta: Gramedia, p. 54

${ }^{3}$ Muhammad Thoha, (2002), Globalisasi: Antara Harapan dan Kecemasan, dalam buku Globalisasi Krisis Ekonomi dan Kebangkitan Ekonomi Kerakyatan, Jakarta: Pustaka Quantum, p. 7

${ }^{4}$ Muladi, "Harmonisasi dan Sinkronisasi Perundang-Undangan tentang Pemberantasan Korupsi", This writing was delivered during Lokakarya Pembentukan Pengadilan Korupsi, organized by Working Group AI KHN, Diponegoro University in BPHN Jakarta on July 30, 2002, p. 1

5 Ibid.

${ }^{6}$ Muladi, (2000), Pengadilan Pidana bagi Pelanggar HAM Berat di Era Demokratisasi, Jurnal Demokrasi dan HAM, Jakarta: The Habibie Centre, p. 39

${ }^{7}$ Mochtar Kusumaatmadja, Pengantar Hukum Internasional, Bandung: Alumni, 2003, p. 7

${ }^{8}$ Muladi, "Proyeksi Hukum Pidana Materiil Indonesia di Masa Mendatang", Pidato Pengukuhan Guru Besar Hukum Pidana pada Fakultas Hukum Universitas Diponegoro, 1990, p. 4
} 
choices for legal policy makers in Indonesia in the context of accommodating international rules, namely:

1) Reject the existence of these legal rules completely and refrain from international influence. If this option is chosen, it means we deny the existence of unity and feel satisfied and strong enough to live alone without depending to other countries. In today's era, the first choice seems impossible to achieve.

2) Model of harmonizing international values into national legal values. Before committing to the harmonization between national law and international law, it is necessary to first examine the extent to which the values in international law can be accepted by using Pancasila as a filter. This means that Indonesian national law must be placed on five basic values.

3) It completely dissolves into the global flow in the sense that all international instruments are taken for granted without regard to national interests.

\section{Women's Protection Strategy in Human Rights Context}

Violence against women is referred to as a global problem due to its correlation to global issue of human rights. Human Rights are defined as the rights that human inherently possess since being born and without that humans cannot live as human beings. These rights include civil and political rights, social, economic and cultural rights and the right to develop.

The relation between violence against women and human rights can be seen from various statements, among others, that violence against women is an obstacle to development. It will reduce women's selfconfidence, inhibit women's ability to participate fully in social activities, disrupt women's health, reduce good women's autonomy in the economic, political, social, cultural and physical fields. Thus, women's ability to take advantage of their lives both physically, economically, politically and culturally is disturbed. In various international conferences, it is said that this issue is affecting Human Development Index. ${ }^{2}$

On 20 December 1993, UN General Assembly accepted the Declaration on the Elimination of Violence Against Women, the declaration which contains an international definition of violence against women. On 6 October 1999, UN General Assembly adopted the Optional Protocol/CEDAW Convention. The protocol is a strategic effort to empower women in eliminating discrimination against themselves and uphold their human rights.

This protocol allows women or a group of women to submit complaints to CEDAW committee, after going through national efforts, about severe and systematic violations that occur to themselves or a group of women, whether carried out by people or countries participating in the CEDAW Convention. This protocol allows two procedures, namely (1) communication procedures, and (2) investigative procedures that allow CEDAW Committee to investigate serious and systematic violations in CEDAW participating countries.

At the national level, the initial efforts have been carried out by ratifying the CEDAW through Law of the Republic of Indonesia Number 7 Year 1984, the enactment of Law of the Republic of Indonesia Number 39 Year 1999 concerning Human Rights, the issuance of Presidential Instruction of the Republic of Indonesia Number 9 Year 2000 concerning Gender Mainstreaming in December 2000, and Law of the Republic of Indonesia Number 23 Year 2004 concerning the Elimination of Domestic Violence was enacted on 22 September 2004.

Violence against women is often related to home and community instability. This can be seen from three categories: First, the condition of poverty will lead to violence to channel frustration and aggression to those who are weak, namely women and children. Second, in an unstable society, a culture of violence will develop. Third, in a society that is turbulent because of war, violence is a part of the weapons used for war.

However, according to Muladi $^{3}$ from the perspective of criminal law, criminology and victimology, a relationship-oriented approach toward the perpetrators and victims must be carried out. In this framework, the identification of victims of violence can be categorized as follows:

a. Victims because of fate.

b. Victims who also provoked.

c. Victims who encourage without provocation.

d. Victims who are physically weak, such as children, women, disabled people.

e. Socially weak victims, such as immigrant groups, minorities.

f. Political casualties.

g. Latent victims, namely those who have behavioural characteristics that always make them victims.

Furthermore, Muladi explained that the problem of violence against women is an interdisciplinary problem, including political and social, culture, economics and other social aspects. On the basis of cross-cultural studies, for example, it can be predicted that violence will occur more frequently where there are economic inequalities between men and women, resolution of conflicts with violence, male domination and family economy and

\footnotetext{
${ }^{1}$ Kartini Sekartadji, "Harmonisasi Hukum Internasional dalam Hukum Nasional pada Era Global”, The writing was delivered in Panel Discussion in Renungan 42 ${ }^{\text {nd }}$ Hari Proklamasi RI, Faculty of Law Diponegoro University, August 15, 1997, p. 8

${ }^{2}$ Muladi, (1997), Hak Asasi Manusia, Politik dan Sistem Peradilan Pidana, Op.Cit., p. 37

${ }^{3}$ Ibid, p. 37
} 
decision-making based on men. Whereas for women in conditions that actually have power outside the house, active community intervention and the development of social protection, family and friends are very low.

From the experience of several countries on their strategies to combat violence against women, it generally includes the following matters:

a. Increasing women's awareness of their rights and obligations in the law through training and counselling. Education as a means of women empowerment is carried out in a universal theme.

b. Increasing public awareness on the importance of efforts to overcome violence against women, both in individual, social and institutional contexts.

c. Given the problem of violence against women is a global issue, it is necessary to coordinate and conduct cross-countries collaborative countermeasures.

d. Increasing awareness of law enforcers, in order to respond immediately in times of violence against women occur, in one spirit that the problem has shifted into a global problem.

e. Increasing assistance and counseling to victims of violence against women.

f. Increasing awareness nationwide through systematic campaigns supported by strong networks. Increasing the role of mass media..

g. Improvement of the criminal justice system, starting from conducive legal reform to respond to violence.

h. Improvement of health service system that is conducive to overcoming violence against women.

Enhancing integrated guidance program for victims and perpetrators. ${ }^{1}$

\section{Conclusion}

Protection of women from violence is our shared responsibility, as individuals, communities, law enforcement and even the government. Legal Politics is carried out in the form of harmonization of laws which emphasizes the existence of the same indicators and characteristics in legislation. While synchronization of law emphasizes that legislation may not conflict with each other by equal legislation (horizontal synchronization) and may not conflict with legislation that higher in hierarchy order (vertical synchronization). Whereas, the strategy of protecting women from violence must be done by: increasing women's awareness of their rights and obligations; increasing public awareness about the importance of efforts to overcome violence against women; need coordination between ministry or non-ministerial institutions whose duty is to provide protection with law enforcement officials (police, prosecutors) in conducting collaborative countermeasures; increasing awareness of law enforcement officials, especially the local police (Polres and Polsek) to act immediately in responding to this violence; increased assistance and counselling for victims; increasing the role of print and electronic media and social media in helping to socialize; improvement of the health care system for victims; and in an integrated manner improving the guidance program for victims and perpetrators.

\section{References}

Achie S. Luhulima, (2000), Pemahaman Bentuk-bentuk Tindak Kekerasan Terhadap Perempuan dan Alternatif Pemecahannya, Working Group "Convention Watch" Gender and Women Research Center, Universitas Indonesia in cooperation with New Zealand Embassy in Indonesia, PT Alumni, Bandung.

Ali Zainuddin, (2006), Filsafat Hukum, Jakarta: Sinar Grafika.

Anthony Giddens, (2001), Runway World, Bagaimana Globalisasi Merombak Kehidupan Kita, Jakarta: Gramedia.

Arief Budiman, (2006), Teori Negara, Negara, Kekuasaan, dan Ideologi, Jakarta: PT Gramedia Pustaka Utama.

Francis Wahono Nitiprawira, “Anatomi Globalisasi dan Agenda Demokrasi”, Jurnal Iman, Ilmu, Budaya,1, (3), September 2002, Yayasan Bhumiksara, Jakarta.

Harkristuti Harkrisnowo, (2001), "Tindak Kekerasan Terhadap Perempuan Dalam Perspektif Sosio Yuridis", Jurnal Hukum, Faculty of Law Universitas Islam Indonesia, Yogyakarta.

https://www.cnnindonesia.com/menguak-data-jumlah-kekerasan-perempuan-tahun-ke-tahun

Kartini Sekartadji, "Harmonisasi Hukum Internasional dalam Hukum Nasional pada Era Global”, The writing was delivered during Panel Discussion Renungan Hari Proklamasi RI ke 42 Faculty of Law Universitas Diponegoro, 15 Agustus 1997.

Maidin Gultom, (2012), Perlindungan Hukum Terhadap Anak dan Perempuan, Bandung: Refika Aditama.

Mochtar Kusumaatmadja, (2003), Pengantar Hukum Internasional, Bandung: Alumni.

Muhammad Thoha, (2002), Globalisasi: Antara Harapan dan Kecemasan, in Globalisasi Krisis Ekonomi dan Kebangkitan Ekonomi Kerakyatan, Jakarta: Pustaka Quantum.

Muladi, (1990), "Proyeksi Hukum Pidana Materiil Indonesia di Masa Mendatang”, Speech was delivered in Criminal Law Professor Inauguration in Faculty of Law Universitas Diponegoro.

${ }^{1} \mathrm{Ibid}$, p. 38 
Muladi, (1997), Hak Asasi Manusia, Politik dan Sistem Peradilan Pidana, Universitas Diponegoro, Semarang.

Muladi, (2000), Pengadilan Pidana bagi Pelanggar HAM Berat di Era Demokratisasi, Jurnal Demokrasi dan HAM, Jakarta: The Habibie Centre.

Muladi, (2002), Demokratisasi, Hak Asasi Manusia, dan Reformasi Hukum di Indonesia, First Edtion, Jakarta: The Habibie Center.

Muladi, "Harmonisasi dan Sinkronisasi Perundang-undangan tentang Pemberantasan Korupsi", The writing was delivered during Lokakarya Pembentukan Pengadilan Korupsi, organized by Working Group AI KHN from Universitas Diponegoro in BPHN Jakarta on July 30, 2002.

Mr. Soplanit, (1997), Kuliah Pengantar Ilmu Hukum.

Peter Mahmud Marzuki. (2006). Penelitian Hukum. Second Edition. Jakarta: Kencana Prenada Media Group.

Reni Widyastuti, (2009), Peran Hukum Dalam Memberikan Perlindungan Terhadap Perempuan Dari Tindak Kekerasan di Era Globalisasi, Mimbar Hukum, 21(2), see https://media.neliti.com/media/publications/40556-ID-peran-hukum-dalam-memberikan-perlindunganterhadap-perempuan-dari-tindak-kekerasan.pdf

Soerjono Soekanto. (2012). Metode Penelitian Hukum. Jakarta: Raja Grafindo.

Tapi Omas Ihromi dkk., (2006), Penghapusan Diskriminasi Terhadap Wanita, Bandung: Alumni.

Wahyu Affandy, (2001), Hakim dan Penegakan Hukum, Bandung: Alumni.

Wila Chandrawila Supriadi, (2001), Kumpulan Tulisan Perempuan dan Kekerasan dalam Perkawinan, Bandung: CV Mandar Maju. 